\title{
STUDIES OF CONGENITAL HEART DISEASE. II. THE PRESSURE AND OXYGEN CONTENT OF BLOOD IN THE RIGHT AURI- CLE, RIGHT VENTRICLE, AND PULMONARY ARTERY IN CONTROL PATIENTS, WITH OBSERVATIONS ON THE OXYGEN SATURATION AND SOURCE OF PULMONARY "CAPILLARY" BLOOD ${ }^{1}$
}

\author{
By L. DEXTER, F. W. HAYNES, C. S. BURWELL, E. C. EPPINGER, R. P. SAGERSON, \\ AND J. M. EVANS
}

(From the Medical Clinic and the Department of Radiology, Peter Bent Brigham Hospital, and the Departments of Medicine and Radiology,. Harvard Medical School)

(Received for publication January 5, 1947)

The venous catheter of Cournand and Ranges (1) permits the measurement of pressure and oxygen content of blood in the pulmonary artery, right ventricle, and right auricle of patients with congenital heart disease. To interpret the data so obtained, it is necessary to be cognizant of the variations in these measurements that occur in patients without congenital cardiac defects. The present report deals with the findings in a group of control patients.

\section{METHODS AND MATERIAL}

The procedures of measuring oxygen consumption, of blood sampling, and of pressure recording in various parts of the right side of the heart have been described in detail in a previous paper (2). The oxygen content of blood was determined by the method of Van Slyke and Neill (3), and pressures were recorded by the optical manometer of Hamilton (4). As noted previously, the zero point for all pressures was taken as $10 \mathrm{~cm}$. anterior to the skin of the back with the patient in the supine position (5). In addition, the anteroposterior diameter of the chest between the sixth thoracic vertebra and the angle of Louis has been recorded for the benefit of those wishing to use another point of reference.

In 13 patients without any evidence of congenital heart disease, the oxygen content of blood and pressures in various parts of the pulmonary artery, right ventricle, and right auricle have been studied (see Table I).

Fifteen patients with a variety of disorders but without clinical or laboratory evidence of auricular septal defect, as noted in Table II, were studied for the purpose of comparing the oxygen content of blood in the right auricle with that in the superior and inferior venae cavae.

In a third group of 16 patients with a variety of abnormalities but without cyanosis (see Table III), the oxygen content of blood obtained from the pulmonary "capillaries" was determined. In addition, 3 patients with right-to-

1 This investigation was aided in part by a grant from the John and Mary Markle Foundation, and from the Proctor Fund of the Harvard Medical School. left shunts have been included (see Table IV). Two of these patients had auricular septal defects (confirmed by autopsy in one case), and the third had the tetralogy of Fallot.

By consulting Tables I, II, and III, it will be noted that the majority of patients were not normal. They were chosen on 2 bases: that they had no defect which would interfere with the interpretation of the results and that they did have a number of abnormalities, such as cardiac failure, anemia, and pulmonary disease, which are sometimes associated with congenital heart lesions. It is believed, therefore, that the values obtained in these patients serve as useful controls for the values observed in patients with congenital cardiac defects.

\section{OBSERVATIONS AND INTERPRETATIONS}

Pressures: Figure 1 illustrates pressure tracings from the pulmonary artery, right ventricle, and right auricle in a normal individual. Gross differences in the pulse wave forms in the different chambers are apparent.

The recording of pressures in patients with congenital heart disease is of particular value in the detection of pulmonary stenosis (6). The systolic pressures in the pulmonary artery and right ventricle were identical within the limit of respiratory variations in each of the patients in Table I. This is in contrast to the findings in pulmonary stenosis where the pulse pressure in the pulmonary artery tends to be narrow and the systolic pressure in the right ventricle is clearly higher than that in the pulmonary artery (6). It is believed that the systolic and diastolic pressures recorded through the catheter with the Hamilton manometer are accurate (2). The finer structure of the pulse waves, especially in the pulmonary artery, is so subject to artefacts that it has not been used by us for analytical purposes. Nevertheless, differences in the gross configura- 


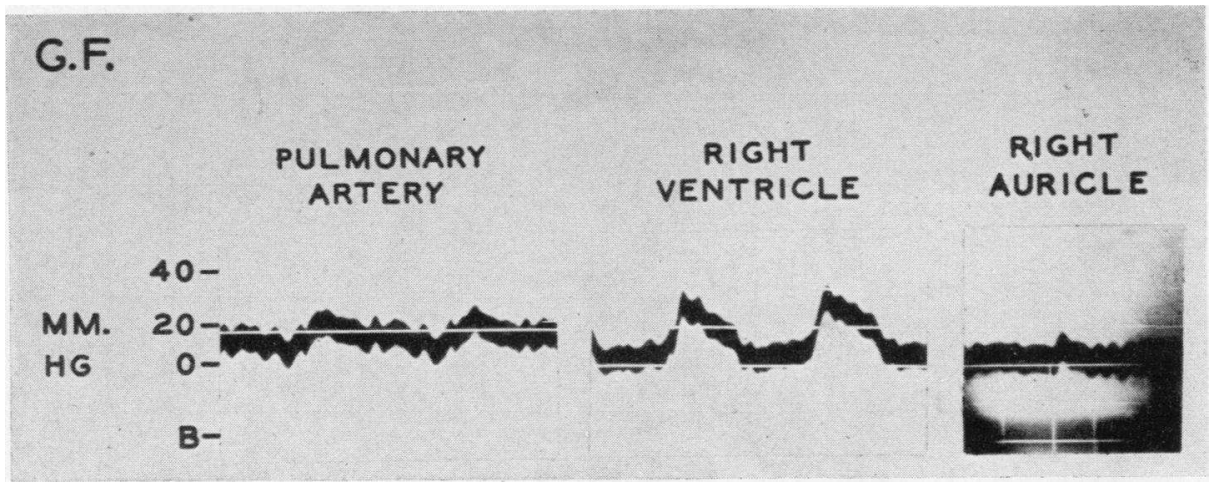

Fig. 1. Pressure Tracings in Pulmonary Artery, Right Ventricle, and Right Auricle of a Normal Patient

The systolic pressures in the pulmonary artery and right ventricle are almost identical, the differences observed being attributable to respiratory fluctuations. Artefacts in the tracings are probably due to the motion of the catheter within the heart and pulmonary artery.

tion of these waves are of the utmost value in identifying the chamber in which the tip of the catheter is located, especially when it lies close to either the pulmonary or the tricuspid valve. This can easily be accomplished at the time of catheterization by noting the deflection of the light beam as the catheter is withdrawn from one chamber to another.

Variations of oxygen content between different chambers: In congenital heart disease, left-to-right shunts introduce arterial blood into the right auricle, right ventricle, or pulmonary artery, thereby increasing the oxygen content of blood within the chamber. Recognition of a significant increase of oxygen in the blood of a given chamber requires a knowledge of the variations that may occur normally. In our control patients (Tables I and II), the greatest increase in the oxygen content of blood in the right auricle over that present in the superior vena cava was 1.9 volumes per cent ( $\mathrm{Ta}$ ble II, patient 9). The greatest increase in the oxygen content of blood in the right ventricle over that present in any part of the right auricle was 0.9 volume per cent (Table I, patients 5 and 12). The greatest increase in the oxygen content of blood in the pulmonary artery over that present in any part of the right ventricle was 0.5 volume per cent (Table I, patient 4). These values are at the moment considered as maximal normal variations with the tentative postulation that a wider divergence is indicative of a shunt of arterial blood into the given chamber. With a larger series of control patients, it is possible that variations encountered between the various chambers would be greater.

It is obvious that left-to-right shunts of small size may be easily overlooked unless the operator can place the tip of the catheter in the stream of arterial blood flowing through the abnormal communication rather than in areas where the arterial stream has become mixed with the surrounding venous blood. This requires knowledge of the probable location of such a shunt as regards not only the chamber involved but also the location of the defect within that chamber. Careful evaluation of the patient by other diagnostic methods is, therefore, essential before performing venous catheterization.

Attempts were made to obtain representative samples of blood from the inferior vena cava by withdrawing the catheter from the region of the renal vein to a point a few centimeters below the diaphragmatic shadow and withdrawing blood samples without further manipulation of the catheter. The oxygen content of blood from the inferior vena cava was uniformly higher than the maximal value obtained from the right auricle. This may well have been due to withdrawal of blood coming predominantly from the renal vein which contains a high content of oxygen (7). In view of this uniform finding, we have abandoned the sampling of blood from the inferior vena cava for comparative purposes and relied solely on that from the superior vena cava. 


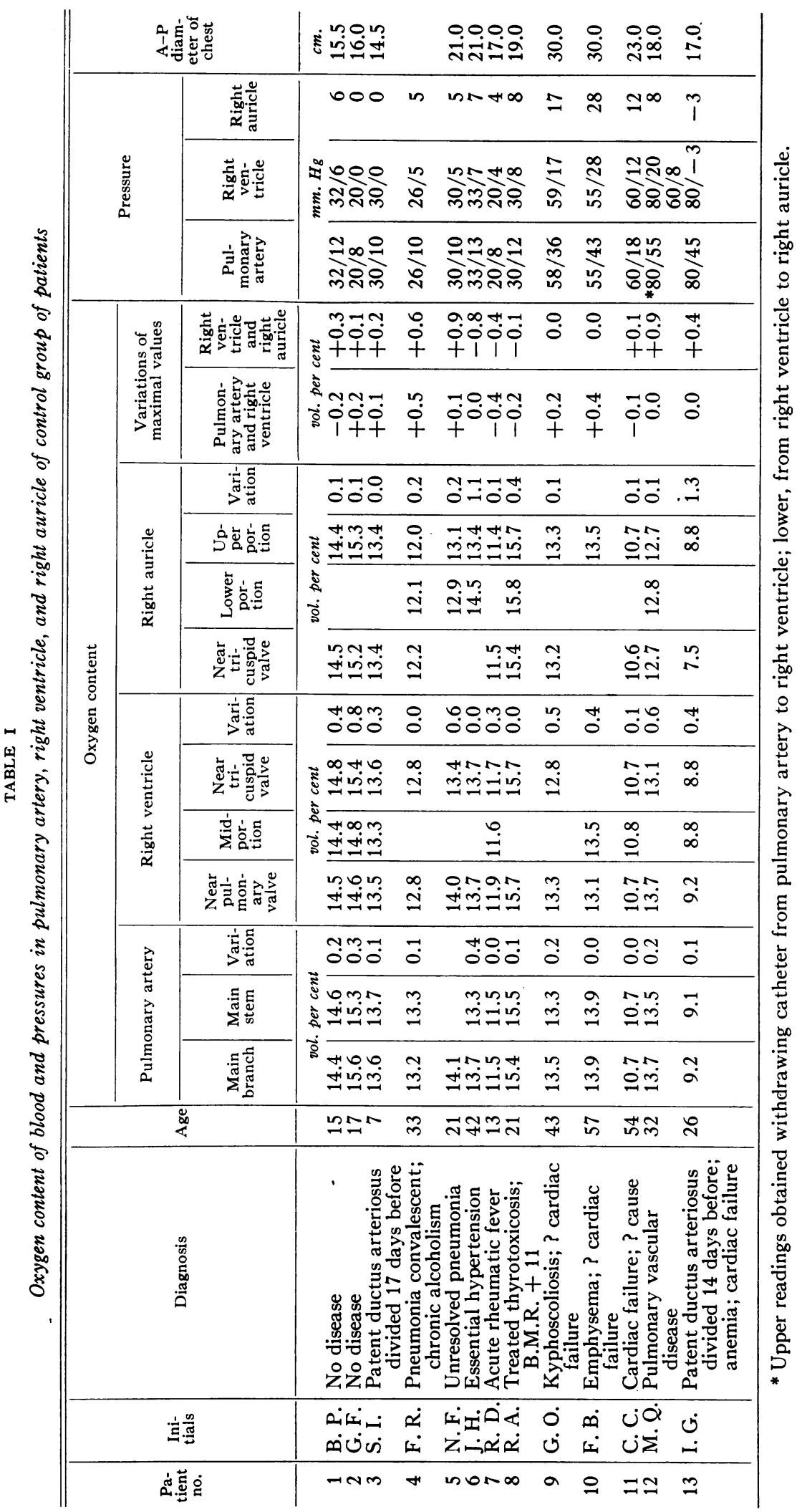


TABLE II

Variations of oxygen content of blood withdrawn from each vena cava and the right auricle

\begin{tabular}{|c|c|c|c|c|c|c|c|c|c|c|}
\hline \multirow{3}{*}{$\begin{array}{c}\text { Patient } \\
\text { no. }\end{array}$} & \multirow{3}{*}{ Initials } & \multirow{3}{*}{ Diagnosis } & \multicolumn{6}{|c|}{ Oxygen content } & \multirow{2}{*}{\multicolumn{2}{|c|}{$\begin{array}{l}\text { Difference between } \\
\text { highest value in } \\
\text { right auricle and } \\
\text { that in the }\end{array}$}} \\
\hline & & & \multirow{2}{*}{$\begin{array}{l}\text { Superior } \\
\text { vena } \\
\text { cava }\end{array}$} & \multicolumn{4}{|c|}{ Right auricle } & \multirow{2}{*}{$\begin{array}{l}\text { Inferior } \\
\text { vena } \\
\text { cava }\end{array}$} & & \\
\hline & & & & $\begin{array}{c}\text { Upper } \\
\text { portion }\end{array}$ & $\begin{array}{l}\text { Near } \\
\text { tricuspid } \\
\text {.valve }\end{array}$ & $\begin{array}{c}\text { Right } \\
\text { middle } \\
\text { portion }\end{array}$ & $\begin{array}{l}\text { Lower } \\
\text { portion }\end{array}$ & & $\begin{array}{c}\text { Superior } \\
\text { vena cava }\end{array}$ & $\begin{array}{l}\text { Inferior } \\
\text { vena cava }\end{array}$ \\
\hline & & & $\begin{array}{c}\text { vol. } \\
\text { per cent }\end{array}$ & \multicolumn{4}{|c|}{ sol. per cent } & $\begin{array}{l}\text { vol. } \\
\text { per cent }\end{array}$ & & \\
\hline $\begin{array}{l}1 \\
2 \\
3\end{array}$ & $\begin{array}{l}\text { G. F. } \\
\text { S. I. } \\
\text { R. D. }\end{array}$ & $\begin{array}{l}\text { Normal } \\
\text { Patent ductus arteriosus } \\
\text { Rheumatic fever, } \\
\text { convalescent }\end{array}$ & $\begin{array}{r}14.8 \\
9.8 \\
10.3\end{array}$ & $\begin{array}{l}15.3^{*} \\
10.0\end{array}$ & 11.5 & $\begin{array}{l}15.2 \\
10.4 \\
11.4\end{array}$ & & & $\begin{array}{l}-0.5 \\
-0.6 \\
-1.2\end{array}$ & \\
\hline $\begin{array}{l}4 \\
5 \\
6\end{array}$ & $\begin{array}{l}\text { H. G. } \\
\text { J. D. } \\
\text { J. H. }\end{array}$ & $\begin{array}{l}\text { Tetralogy of Fallot } \\
\text { Normal } \\
\text { Aortic insufficiency, } \\
\text { ventricular septal defect }\end{array}$ & $\begin{array}{l}17.6 \\
15.7 \\
12.8\end{array}$ & $\begin{array}{l}18.6 \\
16.0 \\
12.1\end{array}$ & $\begin{array}{r}7.2 \\
10.5 \\
12.6\end{array}$ & 18.5 & & 18.0 & $\begin{array}{l}-1.0 \\
-0.3 \\
+0.2\end{array}$ & +2.0 \\
\hline $\begin{array}{r}7 \\
8 \\
9 \\
10\end{array}$ & $\begin{array}{l}\text { H. R. } \\
\text { L. S. } \\
\text { M. T. } \\
\text { S. O. }\end{array}$ & $\begin{array}{l}\text { Duodenal ulcer } \\
\text { Bronchial asthma } \\
\text { Lues, treated } \\
\text { Cystitis; pneumonia, } \\
\text { convalescent }\end{array}$ & $\begin{array}{r}13.1 \\
14.3 \\
9.5 \\
8.7\end{array}$ & $\begin{array}{r}13.4 \\
15.1 \\
10.9 \\
9.3\end{array}$ & $\begin{array}{l}13.6 \\
14.1 \\
11.4 \\
10.0\end{array}$ & & $\begin{array}{l}15.6 \\
11.0 \\
10.1\end{array}$ & $\begin{array}{l}15.1 \\
16.5 \\
12.9 \\
10.3\end{array}$ & $\begin{array}{l}-0.5 \\
-1.3 \\
-1.9 \\
-1.4\end{array}$ & $\begin{array}{l}+1.5 \\
+0.9 \\
+1.5 \\
+0.2\end{array}$ \\
\hline $\begin{array}{l}11 \\
12\end{array}$ & $\begin{array}{l}\text { G. B. } \\
\text { J. M. }\end{array}$ & $\begin{array}{l}\text { Rheumatic heart disease } \\
\text { Uncomplicated pulmonary } \\
\text { stenosis }\end{array}$ & $\begin{array}{l}10.2 \\
14.4\end{array}$ & $\begin{array}{l}10.1 \\
14.3\end{array}$ & 15.2 & 10.4 & $\begin{array}{l}10.4 \\
15.2\end{array}$ & & $\begin{array}{l}-0.2 \\
-0.8\end{array}$ & \\
\hline 13 & M. R. & $\begin{array}{l}\text { Chorea, mitral stenosis, } \\
\text { aortic insufficiency }\end{array}$ & 14.3 & 15.2 & & 15.4 & & & -1.1 & \\
\hline $\begin{array}{l}14 \\
15\end{array}$ & $\begin{array}{l}\mathrm{G} . \\
\mathrm{H} \cdot \mathrm{J} \cdot \dot{G} .\end{array}$ & $\begin{array}{l}\text { Peptic ulcer } \\
\text { Spontaneous pneumothorax }\end{array}$ & $\begin{array}{l}10.6 \\
16.4\end{array}$ & $\begin{array}{l}10.9 \\
17.0\end{array}$ & 11.1 & 16.4 & 11.5 & $\begin{array}{l}12.1 \\
17.4\end{array}$ & $\begin{array}{l}-0.6 \\
-0.6\end{array}$ & $\begin{array}{l}+0.6 \\
+0.4\end{array}$ \\
\hline
\end{tabular}

* Figures in italics represent the highest right auricular values.

** $(+)$ denotes a higher value in the right auricle than in the vena cava; $(-)$ denotes a lower value.

Variation of oxygen content within each chamber: The maximal variation of oxygen content of blood samples obtained from different parts of the right auricle was 11.4 volumes per cent (Table II, patient 4), and 5.5 volumes per cent (Table II, patient 5). In each instance, one sample was highly unoxygenated. The maximal variation within the right ventricle was 0.8 volume per cent (Table I, patient 2). Greater variations than these have been observed in the right ventricle of patients not included in Table I. In 2 patients, variations of 4.5 and 8.4 volumes per cent have been recorded, one of the samples in each case being highly unsaturated. The maximal variation between the trunk and one of the main branches of the pulmonary artery was only 0.4 volume per cent (Table I, patient 6 ) and 0.3 volume per cent (Table I, patient 2).

The accuracy of the direct Fick method for the determination of cardiac output under a given set of conditions depends on the accuracy with which the oxygen consumption and the oxygen content of arterial and mixed venous bloods are determined. This problem has been discussed critically by Cournand ( 8 ), who pointed out that whereas the first two factors are determinable with reasonable accuracy, the third (mixed venous blood) may occasionally be difficult to obtain from the right auricle. Holt and Knoefel (9) reported that true mixing did not occur in the right auricle of dogs. In man, however, Cournand and his associates (8, $10,11)$ concluded that, if the tip of the catheter is located with care in the right auricle close to the tricuspid valve, mixed venous blood is usually obtainable. They showed, however, that even with the catheter in this position in the right auricle, the samples withdrawn were sometimes poorly mixed, as in our case 13 of Table I and in cases 4 and 5 of Table II. Warren, Stead, and Brannon (12) found a maximum variation of oxygen content in the auricle of 2.3 volumes per cent, and in the ventricle 1.8 volumes per cent. They concluded that neither the auricle nor the ventricle could be considered as a source of well-mixed 
venous blood in individual cases, although if groups of cases were treated statistically, good mixing could be considered to have taken place.

Our data confirm the findings of Cournand and his associates and of Warren, Stead, and Brannon in indicating that although adequate mixing usually occurs in the right auricle and right ventricle, unreliable values may at times be obtained. The abnormal values are almost uniformly attributable to low oxygen content of one sample, presumably due to the entrance of coronary venous blood with its low oxygen content (13) into the right ventricle by way of Thebesian vessels and into the right auricle by way of the coronary sinus. It is possible that hepatic venous blood which is low in oxygen (14) may be responsible for the low values in some of the samples obtained from the right auricle.

In contrast to the occasional discrepancies in the oxygen content of blood obtained from right auricle and right ventricle, there was remarkable uniformity in the values obtained from the pulmonary artery. The maximal variations observed hardly exceeded the error of the method of determining oxygen content. It is believed, therefore, that true mixing of venous blood occurs uniformly in the pulmonary artery in man, and that the use of the pulmonary artery as a source of mixed venous blood in determining cardiac outputs by the direct Fick principle will overcome one of the major sources of error of this technique.

Pulmonary "capillary" blood: The oxygen content and saturation of blood obtained through the catheter, when it is introduced into a distal branch of the pulmonary artery so as to occlude it, are shown in Table III. It will be observed that in all cases there was close agreement between the oxygen saturation of this blood and that taken from the femoral artery. In no case did the oxygen saturation of blood from the pulmonary "capillaries" exceed that from the femoral artery by more than 2 per cent. Samples taken from other locations in the pulmonary artery uniformly had lower oxygen saturations. This was also true in the 3 patients with patent ductus arteriosus.

The arterial blood withdrawn when the pulmonary artery is obstructed by the catheter might be derived from anastomoses with bronchial arteries or from the pulmonary capillary and venous bed. The existence of bronchial artery anastomoses proximal to the pulmonary capillaries under normal conditions is doubtful $(15,16)$, although un-

TABLE III

Oxygen content, capacity, and saturation of blood from femoral artery, pulmonary "capillaries," and pulmonary artery in patients without cyanosis

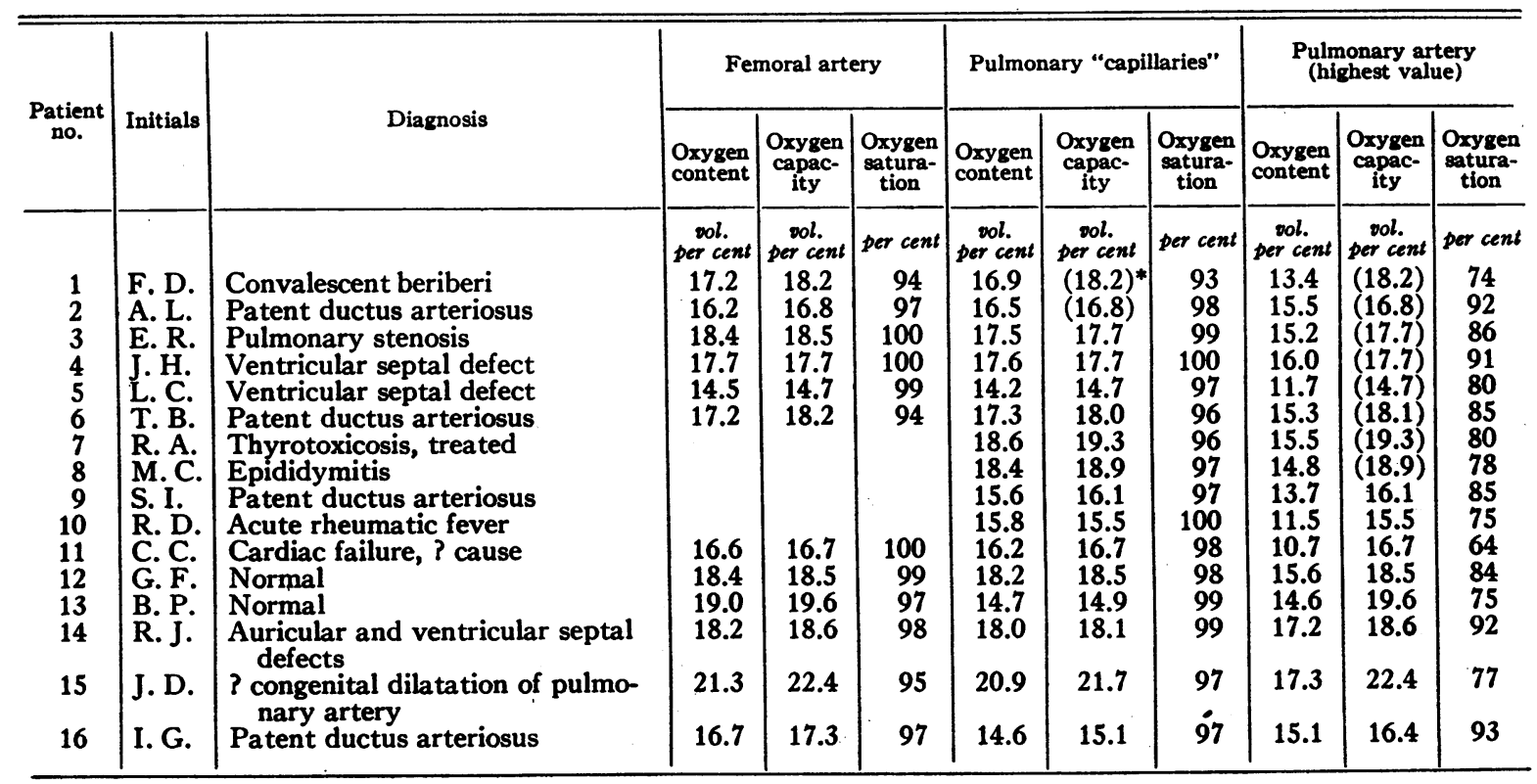

\footnotetext{
* Parentheses indicate that neither the oxygen capacity nor the hemoglobin was determined on the individual sample:
} 
TABLE IV

Oxygen content, capacity, and saturation of blood from femoral artery, pulmonary "capillaries," and pulmonary artery in patients with right-to-left shunts

\begin{tabular}{|c|c|c|c|c|c|c|c|c|c|c|c|c|}
\hline \multirow[b]{2}{*}{$\begin{array}{c}\text { Patient } \\
\text { no. }\end{array}$} & \multirow[b]{2}{*}{$\begin{array}{l}\text { Ini- } \\
\text { tials }\end{array}$} & \multirow[b]{2}{*}{ Diagnosis } & \multicolumn{3}{|c|}{ Femoral artery } & \multicolumn{3}{|c|}{$\begin{array}{l}\text { Pulmonary, } \\
\text { "capillaries" }\end{array}$} & \multicolumn{3}{|c|}{$\begin{array}{l}\text { Pulmonary artery } \\
\text { (highest value) }\end{array}$} & \multirow[b]{2}{*}{$\begin{array}{c}\text { How } \\
\text { diagnosed }\end{array}$} \\
\hline & & & $\begin{array}{l}\text { Oxy- } \\
\text { gen } \\
\text { con- } \\
\text { tent }\end{array}$ & $\begin{array}{c}\text { Oxy- } \\
\text { gen } \\
\text { capac- } \\
\text { ity }\end{array}$ & $\begin{array}{c}\text { Oxy- } \\
\text { gen } \\
\text { satu- } \\
\text { ration }\end{array}$ & $\begin{array}{l}\text { Oxy- } \\
\text { gen } \\
\text { con- } \\
\text { tent }\end{array}$ & $\begin{array}{c}\text { Oxy- } \\
\text { gen } \\
\text { capac- } \\
\text { ity }\end{array}$ & $\begin{array}{l}\text { Oxy- } \\
\text { gen } \\
\text { satu- } \\
\text { ration }\end{array}$ & $\begin{array}{c}\text { Oxy- } \\
\text { gen } \\
\text { con- } \\
\text { tent }\end{array}$ & $\begin{array}{c}\text { Oxy- } \\
\text { gen } \\
\text { capac- } \\
\text { ity }\end{array}$ & $\begin{array}{c}\text { Oxy- } \\
\text { gen } \\
\text { satu- } \\
\text { ration }\end{array}$ & \\
\hline & & & $\begin{array}{l}\text { vol. } \\
\text { per } \\
\text { cent }\end{array}$ & $\begin{array}{l}\text { vol. } \\
\text { per } \\
\text { cent }\end{array}$ & $\begin{array}{l}\text { per } \\
\text { cent }\end{array}$ & $\begin{array}{l}\text { vol. } \\
\text { por } \\
\text { cent }\end{array}$ & $\begin{array}{l}\text { vol. } \\
\text { per } \\
\text { cent }\end{array}$ & $\begin{array}{l}\text { per } \\
\text { cent }\end{array}$ & $\begin{array}{l}\text { vol. } \\
\text { per } \\
\text { cent }\end{array}$ & $\begin{array}{l}\text { vol. } \\
\text { per } \\
\text { cent }\end{array}$ & $\begin{array}{l}\text { per } \\
\text { cent }\end{array}$ & \\
\hline 1 & J.S. & $\begin{array}{l}\text { Auricular septal defect, } \\
\text { chronic nephritis, hyper- } \\
\text { tension, anemia }\end{array}$ & 8.1 & 8.7 & 94 & 8.7 & $(8.8)^{*}$ & 99 & 7.5 & $(8.8)$ & 86 & Autopsy \\
\hline 2 & A. C. & $\begin{array}{l}\text { Auricular septal defect, } \\
\text { secondary polycythemia }\end{array}$ & 25.0 & 32.5 & 76 & 18.5 & 20.5 & 90 & 15.8 & 25.6 & 62 & $\begin{array}{l}\text { Venous } \\
\text { catheteri- }\end{array}$ \\
\hline 3 & E. E. & $\begin{array}{l}\text { Ventricular septal defect, } \\
\text { and pulmonary stenosis }\end{array}$ & 21.1 & 24.2 & 87 & 22.7 & 24.2 & 94 & 17.8 & 24.2 & 74 & $\begin{array}{l}\text { Venous } \\
\text { catheteri- } \\
\text { zation }\end{array}$ \\
\hline
\end{tabular}

* Parentheses indicate that neither the oxygen capacity nor the hemoglobin was determined on the individual sample.

der certain circumstances anastomoses between large bronchial arteries and pulmonary arteries may be striking (17). The finding of a significantly higher oxygen saturation of blood withdrawn from the distal part of the pulmonary artery than in that from the femoral artery in 3 patients with cyanosis from a right-to-left shunt (Table IV) indicates that the blood so obtained does not derive from direct anastomoses with the systemic arterial circulation. It seems justifiable to conclude that it is aspirated mainly from the pulmonary capillary and venous bed. A small pre-capillary source cannot be excluded by these data.

The finding of an oxygen saturation of 95 to 100 per cent in the pulmonary "capillary" blood excludes the existence of pulmonary disease with oxygen diffusion difficulties. The finding of a diminished oxygen saturation, however, does not indicate the presence of pulmonary disease since there may well have been only partial obstruction of the pulmonary arterial branch with some admixture of venous blood from the pulmonary artery. If, in cyanotic patients, values for oxygen saturation in femoral artery and pulmonary "capillaries" are found to be identical and reduced, it is presumptive evidence that the oxygen unsaturation is on the basis of disordered pulmonary function.

Diminution of the oxygen capacity of some of the samples obtained from the pulmonary "capillaries" (see Table II) may well be related to the decreased hematocrit of capillary blood which has been found in samples taken elsewhere in the body (18). Studies of the cause of the variations observed are in progress.

\section{SUMMARY}

1. Venous catheterization of the venae cavae, right auricle, right ventricle, and pulmonary artery has been performed in control patients with various diseases but without congenital defects affecting the factors studied.

2. Pressures and multiple samples of blood for oxygen analysis have been obtained from each chamber.

3. The greatest increase in oxygen from the superior vena cava to the right auricle was 1.9 volumes per cent; from the right auricle to the right ventricle, 0.9 volume per cent; and from the right ventricle to the pulmonary artery, 0.5 volume per cent.

4. The systolic pressure in the pulmonary artery was almost identical with that in the right ventricle over a wide range of pressures.

5. Arterial blood may be obtained from the distal branches of the pulmonary artery by obstructing the artery with the catheter and withdrawing blood through the catheter lumen. Evidence is presented indicating that this blood originates in the pulmonary capillary and venous bed rather than in pre-capillary anastomoses with systemic arteries. 
6. The oxygen content of bloods obtained from several sites within the right auricle and right ventricle showed at times considerable variation, while those from the pulmonary artery were remarkably uniform. It is concluded that mixed venous blood for the determination of cardiac output may be obtained consistently from the pulmonary artery but not uniformly from the right auricle and right ventricle.

\section{ACKNOWLEDGMENT}

The authors wish to express their appreciation to Miss Barbara Jacobs for her technical assistance.

\section{BIBLIOGRAPHY}

1. Cournand, A., and Ranges, H. A., Catheterization of the right auricle. Proc. Soc. Exper. Biol. \& Med., 1941, 46, 462.

2. Dexter, L., Haynes, F. W., Burwell, C. S., Eppinger, E. C., Seibel, R. E., and Evans, J. M., Studies of congenital heart disease. I. Technique of venous catheterization as a diagnostic procedure. J. Clin. Invest., 1947, 26,

3: Peters, J. P., and Van Slyke, D. D., Quantitative Clinical Chemistry. Vol. 2, Methods. Williams \& Wilkins, Baltimore, 1943.

4. Hamilton, W. F., Brewer, G., and Brotman, I., Pressure pulse contours in the intact animal. I. Analytical description of a high frequency manometer. Am. J. Physiol., 1934, 107, 427.

5. Lyons, R. H., Kennedy, J. A., and Burwell, C. S., Measurement of venous pressure by direct method. Am. Heart J., 1938, 16, 675.

6. Dexter, L., Haynes, F. W., Burwell, C. S., Eppinger, E. C., Sosman, M. C., and Evans, J. M., Studies of congenital heart disease. III. Venous catheterization as a diagnostic aid in patent ductus arteriosus, tetralogy of Fallot, ventricular septal defect, and auricular septal defect. J. Clin. Invest., 1947, 26, 561.

7. Warren, J. V., Brannon, E. S., and Merrill, A. J., A method of obtaining renal venous blood in unanes- thetized persons with observations on the extraction of oxygen and sodium para-amino hippurate. Science, 1944, 100, 108.

8. Cournand, A., Measurement of the cardiac output in man using the right heart catheterization. Description of technique, discussion of validity and of place in the study of the circulation. Federation Proc., 1945, 4, 207.

9. Holt, J. P., and Knoefel, P. K., Oxygen content of blood in right auricle and right ventricle. Federation Proc., 1944, 3, 19.

10. Cournand, A., Bloomfield, R. A., and Lauson, H. D., Double lumen catheter for intravenous and intracardiac blood sampling and pressure tracing. Proc. Soc. Exper. Biol. \& Med., 1945, 60, 73.

11. Cournand, A., Riley, R. L., Breed, E. S., Baldwin, E. deF., and Richards, D. W., Jr., Measurement of cardiac output in man using the technique of catheterization of the right auricle or ventricle. J. Clin. Invest., 1945, 24, 106.

12. Warren, J. V., Stead, E. A., Jr., and Brannon, E. S., Cardiac output in man: A study of some of the errors in the method of right heart catheterization. Am. J. Physiol., 1946, 145, 458.

13. Harrison, T. R., Failure of the Circulation. Williams \& Wilkins, Baltimore, 1935, p. 248.

14. Warren, J. V., and Brannon, E. S., A method of obtaining blood samples directly from the hepatic vein in man. Proc. Soc. Exper. Biol. \& Med., 1944, 55, 144.

15. Ghoreyeb, A. A., and Karsner, H. T., A study of the relation of pulmonary and bronchial circulation. J. Exper. Med., 1913, 18, 500.

16. Miller, W. S., The Lung. Charles C. Thomas, Springfield, 1937.

17. Bing, R. J., Vandam, L. D., and Gray, F. D., Jr., Physiological studies in congenital heart disease. II. Results of preoperative studies in patients with tetralogy of Fallot. Bull. Johns Hopkins Hosp., 1947, 80, 121.

18. Ebert, R. V., and Stead, E. A., Jr., Demonstration that the cell plasma ratio of blood contained in the minute vessels is lower than that of venous blood. J. Clin. Invest., 1941, 20, 317. 